\title{
UPAYA MENINGKATKAN KOMPETENSI GURU DALAM TEKNIK PENGOLAHAN DATA PENELITIAN
}

\author{
Neng Murialti*, Dwi Widiarsih, Ranti Darwin, Muhammad Hidayat, \\ M.Fikry Hadi, Mizan Asnawi \\ Prodi Ekonomi Pembangunan, Fakultas Ekonomi dan Bisnis \\ Universitas Muhammdiyah Riau \\ email: neng.murialti@umri.ac.id
}

\begin{abstract}
Higher Education other than as an educational institution that has the main task of carrying out the process of education and teaching, also has other tasks namely carrying out research and community service. Quality improvement of human resources of a nation means encouraging the improvement of the quality of the nation itself so that it has the ability to compete with countries in the world. The education world is one of the spearheads in the effort to improve the quality of human resources. So improving the quality of human resources must be supported by improving the quality of educators (teachers), because qualified teachers will be able to produce students who are also qualified. Efforts to improve the quality of human resources can be implemented jointly in the world of education. Lecturer of Development Economics Study Program Faculty of Economics and Business UMRI tries to help increase teacher competency in Pekanbaru City PGRI Vocational School, through training in the use of SPSS software as a teacher data processing research tool. After conducting data processing training with SPSS software, it is expected that the teacher assemblies can produce quality research to support education and teaching activities at Vocational High School level.
\end{abstract}

Keywords: SPSS, Increased Teacher Competency, improving the quality of HR.

\begin{abstract}
Abstrak
Perguruan Tinggi selain sebagai lembaga pendidikan yang memiliki tugas pokok melaksanakan proses pendidikan dan pengajaran, juga memilki tugas lain yakni melaksanakan penelitian dan pengabdian pada masyarakat. Peningkatan Kualitas SDM suatu bangsa bearti mendorong peningkatan kualitas bangsa itu sendiri sehingga memilki kemapuan bersaing dengan negara-negara di dunia.Dunia pendidikan merupakan salah satu ujung tombak dalam upaya peningkatan kualitas SDM. Maka peningkatan kualitas SDM harus di tunjang dengan peningkatan kualitas pendidik (guru), karena Guru yang berkualitas akan mampu menghasilkan anak didik yang juga berkualitas. Upaya peningkatan kualitas SDM dapat dilaksanakan secara bersama di dunia pendidikan. Dosen Program Studi Ekonomi Pembangunan Fakultas Ekonomi dan Bisnis UMRI berusaha Membantu peningkatan kopetensi guru di SMK PGRI Kota Pekanbaru, melalui pelatihan penggunaan software SPSS sebagai alat pengolahan data penelitian para guru. Setelah di adakan pelatihan pengolahan data dengan software SPSS diharapkan para majelis guru dapat menghasilkan penelitian yang berkualitas untuk menunjang kegiatan pendidikan dan pengajaran di tingkat Sekolah Menengah Kejuruan.
\end{abstract}

Kata kunci: SPSS, Peningkatan Kopetensi Guru, peningkatan kualitas SDM. 


\section{PENDAHULUAN}

Guru memiliki peran yang strategis dalam upaya meningkatkan kualitas pendidikan sehingga ada slogan no teacher, no education yang berarti tidak ada guru, tidak ada pendidikan. Dengan kata lain guru merupakan komponen kunci dalam upaya peningkatan kualitas pendidikan dan menjadi salah satu penentu keberhasilan pendidikan. Hal ini sangat wajar karena guru yang secara langsung berinteraksi edukatif dengan peserta didik, sehingga berbagai permasalahan yang ada dalam pembelajaran dapat langsung diketahui oleh guru untuk dicarikan solusi pemecahannya.

Dalam rangka pengembangan profesional, guru tidak bisa melepaskan dirinya dari kegiatan akademik penelitian. Penelitian yang terkait langsung dengan tugas pokok dan fungsinya serta berdampak langsung terhadap peningkatan kualitas pembelajaran. Dalam kegiatan penelitian ini, guru memiliki peran strategis dalam pengembangan kompetensi profesional sekaligus sebagai upaya dalam meningkatkan dan memperbaiki proses maupun hasil belajar siswa [1].

Adanya sebuah penelitian tidak bisa lepas dari munculnya masalah, kemudian dari masalah tersebut kita mencoba menggali informasi lebih banyak agar diperoleh data yang valid. Di era yang serba modern ini suatu data menjadi hal yang sangat penting bagi kehidupan. Hampir dalam kehidupan sehari-hari kita tidak akan lepas dari yang namanya informasi.

Tanpa adanya suatu informasi maka kita tidak mengetahui info-info terbaru dan tidak dapat menyelesaikan berbagai macam masalah. Dan tanpa adanya suatu data yang dicari sebelumnya maka tidak akan ada yang namanya informasi dan solusi untuk masalah yang kita lihat dan hadapi.
Berdasarkan penjelasan yang terdapat pada latar belakang dapat dirumuskan beberapa permasalahan yaitu penerapan teknik analisis data dalam penelitian ilmiah.

Tujuan yang hendak dicapai dalam usaha ini adalah: 1) Memberikan pelatihan cara Pengolahan data penelitian dengan menggunakan software SPSS; 2) Meningkatkan kompetensi guru dalam melakukan penelitian.

Dari pelatihan ini diharapkan dapat memberikan manfaat sebagai berikut :

1) Bagi pihak sekolah yaitu pelatihan dalam bentuk pengabdian masyarakat yang dilakukan oleh dosen Fakultas Ekonomi untuk meningkatkan kemampuan dan kompetensi guru dalam penggunaan software SPSS sebagai alat pengolahan dan analisis data penelitian

2) Bagi Perguruan tinggi kegiatan ini sebagai bentuk Catur Dharma Perguruan Tinggi Muhammadiyah.

3) Bagi para guru diharapkan dapat meningkatakan kuantitas dan kualitas penelitian dalam upaya peningkatan kualitas guru dalam penelitian.

4) Bagi dosen, melalui kegiatan ini dapat mengembangkan wawasan kemasyarakatan kalangan dosen dan mahasiswa, sehingga nantinya akan terjalin komunikasi yang efektif antar perguruan tinggi dengan masyarakat dalam bentuk pemberdayaan sumber daya masyarakat yang luas.

Pada dasarnya data adalah kumpulan informasi atau keterangan keterangan dari suatu hal yang diperoleh melalui pengamatan atau pencarian ke sumber - sumber tertentu. Data yang diperoleh dapat menjadi suatu anggapan atau fakta karena memang belum diolah lebih lanjut. Setelah diolah melalui 
penelitian atau percobaan maka suatu data dapat menjadi bentuk yang lebih kompleks seperti suatu database, informasi atau bahkan solusi untuk masalah tertentu [2]

Dari segi Bahasa kata "data" diambil dari kata "datum" yang dalam Bahasa Romawi diartikan sebagai sesuatu yang diberikan. Oleh karena itu definisi sesungguhnya dari data adalah diberikan bukan memberikan, karena jika memberikan maka data itu sudah menjadi informasi yang baku dan diakui kebenarannya. Istilah data memang lebih banyak ditemui pada bidang komputer atau dalam lingkup suatu penelitian [3]

Dalam bidang komputer kita sering mendengar tentang database ataupun software pengolah data. Sedangkan dalam lingkup penelitian, sudah menjadi hal yang wajib bahwa setiap peneliti terlebih dahulu harus mencari data dengan melakukan observasi (pengamatan) sebelum dikaji lebih lanjut dan akhirnya diperoleh hasil penelitian. Hal ini juga sering dijumpai dalam bidang pendidikan seperti pembuatan jurnal.

Data berfungsi untuk membuat keputusan terbaik dalam memecahkan masalah, dapat dijadikan sebagai dasar suatu perencanaan atau penelitian, dijadikan sebagai acuan dalam setiap implementasi suatu kegiatan dan terakhir data juga dapat dijadikan sebagai bahan evaluasi. Suatu data dapat diibaratkan sebagai dasar perencanaan atau riwayat segala tindakan yang sudah dilakukan. Inilah mengapa hampir dalam semua aspek kehidupan melibatkan suatu data.

\section{Jenis - Jenis Data}

Karena hampir ada di segala aspek kehidupan maka data dapat dikelompokkan menjadi beberapa jenis. Terdapat banyak parameter pengelompokan data namun kebanyakan dikelompokkan berdasarkan sifatnya, berdasarkan sumber atau darimana data itu berasal, berdasarkan waktu pengambilan dan lain-lain.masih.

\section{Berdasarkan sumbernya}

Sebelumnya sempat dibahas bahwa suatu data itu diperoleh dari cara memperoleh yang berbeda. Perbedaan sumber ini juga dapat mengelompokkan data menjadi beberapa jenis yakni data primer dan data sekunder.

Data primer atau data asli ini diperoleh dari sumber-sumber tertentu yang didapat objek penelitian.

Data sekunder atau data tambahan biasanya diperoleh dari sumber - sumber terdahulu seperti buku, jurnal dan lain lain.

\section{Berdasarkan sifat-sifatnya}

Suatu data juga dapat dibedakan berdasarkan sifat - sifatnya yakni data kualitatif dan data kuantitatif. Kedua jenis data ini juga sering digunakan dalam berbagai kesempatan penelitian yang pernah dilakukan sebelumnya

Data kualitatif biasanya banyak dijumpai dalam berbentuk pernyataan verbal, gambar atau bahkan simbol. Data kuantitatif lebih mengarah kepada pernyataan secara terbilang atau angka [4]

\section{Berdasarkan waktu pengambilannya}

Selanjutnya suatu data juga dapat dikelompokkan berdasarkan waktu pengambilan atau pengumpulannya. Terdapat jenis data yang dikumpulkan secara berkala dan data cross section.

Setelah membaca artikel mengenai pengertian data yang kami buat diatas dapat diambil kesimpulan bahwa suatu data memang saat ini sudah menjadi kebutuhan pokok bagi masyarakat. Namun amat disayangkan pada kenyataannya masih banyak orangorang yang kurang memahami definisi suatu data atau justru mengerti tapi berusaha untuk menyalahgunakan pemanfaatan data, oleh karena itu kami 
mengharapkan pembaca dapat menyadari hal ini dan dapat memanfaatkan data yang diperoleh secara maksimal.

\section{Software Pengolahan Data \\ 1. SPSS}

Tentu Anda sering mendengar program statistika satu ini, di perkuliahan atau pun di beberapa perusahaan besar pun menggunakan software statistika ini. SPSS singkatan dari Statistical Package for the Social Software. Pertama kali dirilis pada tahun 1968 yang dikembangkan oleh Norman H. Nie dan C. Hadlai Hull [5], [6]

SPSS pertama kali muncul dengan versi PC dengan nama SPSS/PC+ (versi DOS). SPSS pada awalnya dibuat untuk keperluan pengolahan data statistik untuk ilmu-ilmu sosial (sesuai dengan singkatan dari SPSS itu sendiri) [7]

\section{HASIL DAN PEMBAHASAN}

Pelaksanaan kegiatan Pengabdian Kepada Masyarakat yang dilakukan di Sekolah Menengah Kejuruan (SMK) PGRI yang beralamat di Jln. Brigjen Katamso N.o 46 Bukit Raya Kota Pekanbaru telah berjalan dengan baik dan terlaksana sesuai dengan waktu yang direncanakan sebelumnya. Tim Pelaksana PKM ini adalah Program Studi Ekonomi Pembangunan, Fakultas Ekonomi dan Bisnis Universitas Muhammadiyah Riau mendapatkan sambutan yang sngat baik dari Sekolah menengah Kejuruan (SMK) PGRI Kota Pekanbaru.

Berjalannya kegiatan PKM ini melalui beberapa tahap.Tahap Pertama adalah melakukan persiapan, dimana pada tahap ini dimulai dengan mempersiapkan proposal kegiatan PKM. Tahap kedua melakukan observasi dan permohonan izin kepada pihak Sekolah Menengah Kejuruan (SMK) PGRI Kota Pekanbaru sebagai tempat dilakukannya PKM. Tahap ketiga mengumpulkan informasi mengenai jumlah peserta yaitu Majelis Guru yang akan mengikuti pelatihan pengolahan data di SMK PGRI Pekanbaru.Tahapan terakhir melakukan kesepakatan waktu pelaksanaan antara pemateri, seluruh dosen Prodi Ekonomi Pembangunan Fakultas Ekonomi dan Bisnis Umri dan seluruh Majelis Guru SMK PGRI yang akan Mengikuti pelatihan.

Setelah waktu pelaksanaan kegiatan disepakati, Pihak pelaksana segera melengkapi segala atribut untuk penunjang kelancaran pengabdian ini. Keberlangsungan kegiatan pengabdian ini juga melibatkan mahasiswa dari Program Studi Ekonomi Pembangunan.

Pada tahap pelaksanaan kegiatan. Sebelum melakasanakan kegiatan PKM, tim pelaksana melaksanakan tahap persiapan dengan melakukan briefing untuk penyiapan Master Software SPSS dengan menginstalkan program tersebut dilabor komputer dan Laptop majelis guru, selain itu juga membagi job descreption masing-masing pembicara, menyiapkan para peserta pelatihan, menyiapkan materi pelatihan yang berhubungan dengan peningkatan kopetensi guru dalam pengolahan data penelitian dengan menggunakan Software SPSS.

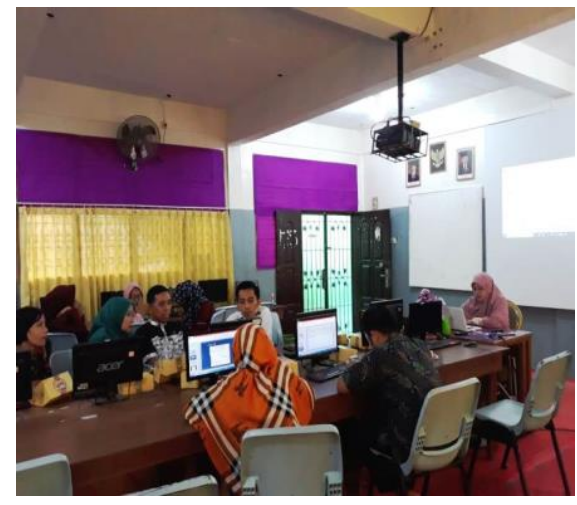

Gambar 3.1: Pelatihan Pengolahan Data Bersama Guru-Guru SMK PGRI Pekanbaru

Setelah pengolahan data selesai, dilakukan pembacaan/ analisis hasil 
pengolahan data sesuai dengan jenis statistik yang di pilih dengan diskusi dengan pemateri. Seluruh majelis guru yang ikut pelatihan diberikan kesempatan untuk berdiskusi dengan pemateri terkait materi yang disampaikan serta melakukan latihan sendiri sesuai dengan contoh soal yang di berikan.

Pada tahap terakhir masing-masing majelis guru diberikan kesempatan untuk melakukan pengolahan data dengan contoh kasus yang sudah disediakan oleh narasumber/ pemateri sesuai dengan kebutuhan para guru, seperti penelitian pengujian apakah terdapat perbedaan kinerja guru sebelum dan setelah pelatihan. Setelah pengolahan data juga diberikan kesempatan kepada majelis guru untuk membaca dan menganalisis hasil penelitian dan membuatkan kesimpulan dari hasil penelitiannnya. Disamping itu majelis guru juga diberikan kesempatan untuk berdiskusi dengan para dosen dan pemateri terkait penelitian yang mereka lakukan.

Tujuan dari kegiatan pelatihan ini dilaksanakan adalah dalam rangka pelaksanaan Catur Dharma Perguruan Tinggi Muhammadiyah, yang salah satunya adalah pengabdian pada masyarakat. Pelatihan ini ditujukan untuk majelis Guru di Sekolah Menengah Kejuruan (SMK) PGRI Pekanbaru, adapun bentuk pelatihan adalah pengolahan data penelitian dengan menggunakan Software SPSS dengan tujuan untuk meningkatkan kopetensi majelis guru dalam pengolahan data penelitian guna

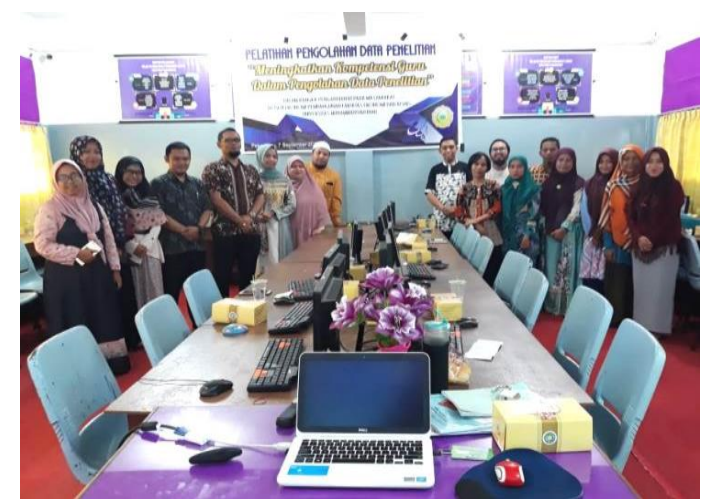

Gambar 3.2: Foto Bersama Guru-Guru SMK PGRI Pekanbaru

Evaluasi pada tahap pertama telah sesuai dengan indikator dan rancangan evaluasi diperoleh data sebgai berikut:

1. Jumlah peserta yang hadir sebanyak 55 orang dari 60 peserta sehingga tingkat kehadiran mencapai $92 \%$.

2. Peserta pelatihan adalah Majelis Guru di Sekolah Menengah Kejuruan (SMK) PGRI Pekanbaru terlihat sangat antusias selama mengikuti pelatihan pengolahan data dengan menggunakan Software SPSS dari awal kegiatan dimulai hingga pelatihan selesai

3. Para Majelis Guru diberi kesempatan untuk mempraktekan secara langsung teknik pengolahan data dengan menggunakan software SPSS dengan menggunakan contoh data yang sudah di persiapkan oleh pemateri/ narasumber.

4. Setelah dilakukan pelatihan diharapkan seluruh Majelis Guru di SMK PGRI Pekanbaru dapat mengolah data penelitian mereka serta mampu menganalisis hasil penelitian mereka, sehingga dapat meningkatkan kopetensi mereka dalam peningkatan kualitas pendidikan di tempat mereka mengajar dan memberikan dorongan kepada para majelis guru untuk menghasilkan penelitian yang 
dapat bermanfaat bagi sekolah dan siswa di SMK PGRI Kota Pekanbaru.

5. Setelah kegiatan ini selesai dilaksanakan, maka tim pelaksana melakukan evaluasi. Adapun evaluasi dari kegiatan ini dapat dinyatakan secara umum berhasil dengan baik dan memuaskan seluruh Majelis Guru SMK PGRI di Kota Pekanbaru yang ikut pelatihan dan juga narasumber/pemateri. Pelatihan ini mendapatkan sambutan dan respon yang sangat antusias dari pihak sekolah umumnya dan Majelis Guru yang mengikuti pelatihan khususnya. Majelis Guru SMK PGRI di Kota Pekanbaru berharap ada kerja sama antara pihak UMRI khususnya prodi Ekonomi Pembangunan dengan SMK PGRI Kota Pekanbaru dengan menjadikan SMK PGRI Kota Pekanbaru sekolah Binaan terutama dalam peningkatan kualitas guru dan kualitas pendidikan di SMK PGRI Kota Pekanbaru, sehingga mampu bersaing mendapatkan kepercayaan masyarakat dan menjadikan SMK PGRI kota pekanbaru sebagai tempat pendidikan anak-anak mereka di tingkat Sekolah Menengah Kejuruan.

\section{SIMPULAN}

Kegiatan pengabdian kepada masyarakat berupa kegiatan pelatihan pengolahan data dengan menggunakan software SPSS yang diadakan di SMK PGRI Kota Pekanbaru secara keseluruhan dapat berjalan baik dan lancar. Pelatihan ini memberikan keterampilan mengoalah data penelitian dan kemampuan menganalisis hasil pengoalahan data penelitian sesuai kebutuhan para majelis Guru di tingkat
Sekolah Menengah Kejuruan. Pelatihan Penggunaan Software SPSS ini diharapkan dapat membangkitkan semangat para Majelis Guru di SMK PGRI Kota Pekanbar SMK PGRI di Kota Pekanbaru bagi pihak sekolah khusunya dan masyarakat pada umumnya sehingga mampu meningkatkan kepercayaan masyarakat untuk menitipkan anak-anak mereka menimba ilmu di Sekolah Menengah Kejuruan PGRI Kota Pekanbaru.

\section{SARAN}

Bagi peserta (majelis Guru) disarankan untuk terus meningkatkan kopetensi dengan cara terus berlatih dalam penggunaan software SPSS untuk mengolah data statistik baik parametrik dan non parametrik sehingga kualitas penelitian para Guru dapat.

Kepada Pihak sekolah diharapkan dapat memfasilitasi guru dalam peningkatan kopetensi guru sehingga para guru di SMK PGRI Kota Pekanbaru memiliki kopetensi yang lebih di bandingkan dengan guru-guru di (SMK) yang lain sehingga sekolah memilki nilai jual yang tinggi dalam mendidik siswanya dan memperbesar kepercayaan para orang tua wali untuk menitipkan anak-anak mereka. Pendidikan yang berkualitas sangat tergantung pada sumber daya manusia yang ada di sekolah tersebut (majelis Guru).

\section{DAFTAR PUSTAKA}

[1] I. G. Agung, 'Penerapan Pengajaran Kontekstual Berbasis Masalah Untuk Meningkatkan Hasil Belaajar Biologi Siswa Kelas X SMA Laboratorium Singaraja', J. Penelit. dan Pengemb. Pendidik., 2008.

[2] D. N. Gujarati, Basic Econometrics. 2004.

[3] I. Ghozali, 'Aplikasi Analisis Multivariate Dengan Program IBM dan SPSS 21', in Aplikasi 
Analisis Multivariate dengan Pogram iIBM SPSS 21, 2016.

[4] Sugiyono, 'Perspektif Metode Penelitian Kuantitatif Dan Kualitatif', in Metodelogi Penelitian kuantitatif dan kualitatif, 2014.

[5] A. Muhson, 'Teknik Analisis Kuantitatif', Makal. Tek. Anal. II, 2006.

[6] I. Ghozali, 'Analisis Multivariate dengan program IBSM SPSS21', Semarang Univ. Diponegoro, 2013.

[7] Suharyadi, Purwanto S.K, 'Statistika Deskriptif', Stat. untuk ekon. dan Keuang. Mod., 2003. 